Article

\title{
Impact Assessment and Geochemical Background Analysis of Surface Water Quality of Catchments Affected by the 2017 Portugal Wildfires
}

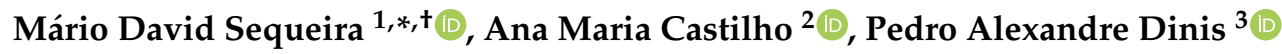 \\ and Alexandre Oliveira Tavares 1 \\ 1 Centre for Social Studies, Department of Earth Sciences, Faculty of Sciences and Technology, \\ University of Coimbra, 3030-790 Coimbra, Portugal; atavares@ci.uc.pt \\ 2 Geosciences Centre, Department of Earth Sciences, Faculty of Sciences and Technology, \\ University of Coimbra, 3030-790 Coimbra, Portugal; amcastil@dct.uc.pt \\ 3 MARE-Marine and Environmental Sciences Centre, Department of Earth Sciences, \\ Faculty of Sciences and Technology, University of Coimbra, 3030-790 Coimbra, Portugal; pdinis@dct.uc.pt \\ * Correspondence: mario.sequeira@uc.pt \\ † Current Address: Departamento de Ciências da Terra, Rua Sílvio Lima, Universidade de Coimbra-Pólo II \\ 3030-790 Coimbra, Portugal.
}

Received: 4 September 2020; Accepted: 28 September 2020; Published: 30 September 2020

\begin{abstract}
In October 2017, the Mondego hydrological basin was devastated by multiple wildfires. To understand the impacts that these had on surface water quality, monthly monitoring campaigns were implemented in the affected catchments. The campaigns oversaw the water's physical characteristics and major, minor and trace constituents. Analysis of major changes was performed, as well as comparisons with geochemical backgrounds, determined using publicly available data collected prior to the fires. The backgrounds allowed us to verify which water parameters were most influenced by the fires. Wildfires were responsible for increasing turbidity on all watercourses, and electrical conductivity increased in watercourses with flatter, granitoid/sedimentary-dominated watersheds. $\mathrm{Cl}^{-}, \mathrm{NO}_{3}{ }^{-}$, and $\mathrm{SO}_{4}{ }^{2-}$ surpassed background values in most monitored basins. Changes in $\mathrm{Al}, \mathrm{Fe}$, $\mathrm{Mn}, \mathrm{As}, \mathrm{Ba}$, and $\mathrm{Zn}$ concentrations were observed in all watercourses after the wildfires and decreases after intense rainfall. Background values were particularly exceeded for $\mathrm{Al}$ in all monitoring points and As in basins with extensive agricultural areas. Burnt plant material and organic matter partially account for the increases in $\mathrm{Cl}^{-}, \mathrm{NO}_{3}{ }^{-}, \mathrm{SO}_{4}{ }^{2-}, \mathrm{Al}, \mathrm{As}, \mathrm{Fe}$, and Mn content. High $\mathrm{Al}, \mathrm{Fe}$ and $\mathrm{Zn}$ with low water conductivity suggests that these elements were associated with sediment loads after the removal of vegetation.
\end{abstract}

Keywords: surface water monitoring; physical and chemical parameters; rural fires; geochemical background; land-use change

\section{Introduction}

Portugal rural fires have been a major point of national concern due to their incidence and severity [1-5]. The regional distribution of forest fire ignitions and burnt areas in mainland Portugal reflect a close relationship between biophysical and human variables [6,7]. Although the meteorological conditions are crucial in the ignition and during the fire spread, there is a positive trend for increasing burnt areas related to changes in farming and land use [8]. Because of the changes in climatic patterns [9-12] and in the way land is used, especially land abandonment and introduction of pine and eucalypt [6,13-16], fire activity in the Mediterranean region has escalated in the last two decades [17], with Portugal being the European country most affected by fires [18]. The impacts of rural fires on 
public policies have been highlighted and extensively covered by the media $[3,19,20]$. In 2017, when the country was suffering a severe drought, two major fire events devastated around $5000 \mathrm{~km}^{2}$ [21]. While the first was mostly characterized by the massive number of deaths, the second one, in October, under the influence of Hurricane Ophelia, was marked by the sheer size of the burnt area [21].

Streamflow transfer and erosion processes is affected by wildfires [22,23]. The precipitation after forest fires tends to augment the runoff and erosion, due to partial or complete destruction of vegetation and litter cover [14,24] and changes of soil properties [25,26], sometimes with enhanced water repellency $[27,28]$.

Fires have also been linked to changes in the water's chemical and biological constituents, in particular after the beginning of rainfall as sediments, ashes, debris and products of combustion, carried by the runoff reach the watercourses [22,24]. Contributions of $\mathrm{N}$ and $\mathrm{P}$ to watercourses resulting from fire activity were reported before [29-31], as well as $\mathrm{SO}_{4}{ }^{2-}[29,31]$, due to sulfur oxidation during combustion of the organic matter [22] and release of $\mathrm{Cl}^{-}$from burnt vegetation [31]. Studies on the effects on trace elements and other compounds are less prominent [22]. As happened after the Cerro Grande Fire in Los Alamos (USA) [32], significant amounts of Al, As, Fe, and Mn were measured in small basins of central Portugal after the forest fires of 2017 [33]. It is, however, unclear whether the measured concentrations can be considered abnormal and how they vary with geomorphological conditions.

A particular strategy to perceive changes in water quality after forest fires is a comparison of a burnt area with an unburnt control region $[30,31,34,35]$. This procedure is not feasible where fire effects in regions with diversified geomorphological features are meant to be investigated. Establishing normal concentrations in watercourses is a practical alternative to detect abnormal element concentrations [36]. Many methods have been applied to identify normal concentration in a medium, namely a "threshold" calculation [37], geochemical background [38], and the natural background levels [39]. Using the median \pm median absolute deviation is a procedure that does not rely on statistical assumptions and has the advantages of being particularly effective against data outliers commonly found on datasets, delivering conservative values [38], and being preferred in ecological studies [40].

In order to understand the surface water changes on the Mondego River after the forest fires of October 2017, 10 surface water sampling points, representing catchment basins with different physiographic, lithological, land use features and extension of fire-affected areas, were selected for a series of seven monthly monitoring campaigns (Table 1). This work served to test a methodology that would allow the determination of a surface water geochemical background using 30-year data. Combining the results obtained from a series of monitoring campaigns on affected areas, with background levels for the same watercourses, should provide safe information on the effects that the rural fires of 2017 had on the watercourses of the Mondego River hydrological basin.

Table 1. Monitored watercourses, their reference (Ref.), location, average slope (Av. Slp), watershed areas (Area), spring distance (Spr.), and their respective burn area percentages (B.A.).

\begin{tabular}{cccccccc}
\hline Watercourse & Ref. & Latitude & Longitude & Av. Slp $\left(^{\circ}\right)$ & Area $\left.\mathbf{( k m}^{2}\right)$ & Spr. $(\mathbf{k m})$ & B.A. $(\%)$ \\
\hline Mondego $^{1}$ & RM1 & $40^{\circ} 24^{\prime} 09.36^{\prime \prime} \mathrm{N}$ & $7^{\circ} 59^{\prime} 09.26^{\prime \prime} \mathrm{W}$ & 6.7 & 1421.6 & 124.1 & 44.2 \\
Cavalos & CAV & $40^{\circ} 22^{\prime} 28.74^{\prime \prime} \mathrm{N}$ & $7^{\circ} 59^{\prime} 35.23^{\prime \prime} \mathrm{W}$ & 4.5 & 86.8 & 13.4 & 83.6 \\
Covelo & COV & $40^{\circ} 19^{\prime} 40.22^{\prime \prime} \mathrm{N}$ & $8^{\circ} 05^{\prime} 36.89^{\prime \prime} \mathrm{W}$ & 4.1 & 20.9 & 3.5 & 68.3 \\
Pomares & $\mathrm{POM}$ & $40^{\circ} 17^{\prime} 32.14^{\prime \prime} \mathrm{N}$ & $7^{\circ} 54^{\prime} 13.21^{\prime \prime} \mathrm{W}$ & 18.3 & 44.7 & 10.8 & 99.2 \\
Cerdeira & $\mathrm{CRD}$ & $40^{\circ} 15^{\prime} 58.21^{\prime \prime} \mathrm{N}$ & $7^{\circ} 59^{\prime} 14.21^{\prime \prime} \mathrm{W}$ & 14.0 & 43.0 & 9.7 & 99.2 \\
Alva $^{1}$ & $\mathrm{RA} 1$ & $40^{\circ} 16^{\prime} 12.83^{\prime \prime} \mathrm{N}$ & $7^{\circ} 59^{\prime} 18.64^{\prime \prime} \mathrm{W}$ & 14.9 & 433.3 & 50.0 & 52.0 \\
Alva $^{2}$ & $\mathrm{RA} 2$ & $40^{\circ} 17^{\prime} 42.47^{\prime \prime} \mathrm{N}$ & $8^{\circ} 14^{\prime} 43.94^{\prime \prime} \mathrm{W}$ & 12.2 & 705.9 & 107.6 & 49.8 \\
Ceira $^{1}$ & $\mathrm{RC} 1$ & $40^{\circ} 08^{\prime} 19.72^{\prime \prime} \mathrm{N}$ & $7^{\circ} 59^{\prime} 54.69^{\prime \prime} \mathrm{W}$ & 17.7 & 159.4 & 39.1 & 82.7 \\
Ceira $^{2}$ & $\mathrm{RC} 2$ & $40^{\circ} 09^{\prime} 42.88^{\prime \prime} \mathrm{N}$ & $8^{\circ} 16^{\prime} 40.08^{\prime \prime} \mathrm{W}$ & 14.6 & 412.6 & 85.9 & 48.6 \\
Mondego $^{2}$ & $\mathrm{RM} 2$ & $40^{\circ} 12^{\prime} 03.38^{\prime \prime} \mathrm{N}$ & $8^{\circ} 25^{\prime} 39.83^{\prime \prime} \mathrm{W}$ & 7.6 & 4905.6 & 188.5 & 39.0 \\
\hline
\end{tabular}




\section{Materials and Methods}

\subsection{Area Description}

The 2017 fires were responsible for a death toll of 64 citizens in July [41], with 51 in October [42], along with half of the $4400 \mathrm{~km}^{2}$ of area that burnt that year [43]. The study region, the Mondego River drainage basin in Portugal's central region, was harshly affected by the 2017 wildfires (30\% of burnt area) (Figure 1a). During the next months, it was still possible to observe ashes and other combustion products in the margins of the watercourses (Figure 2).

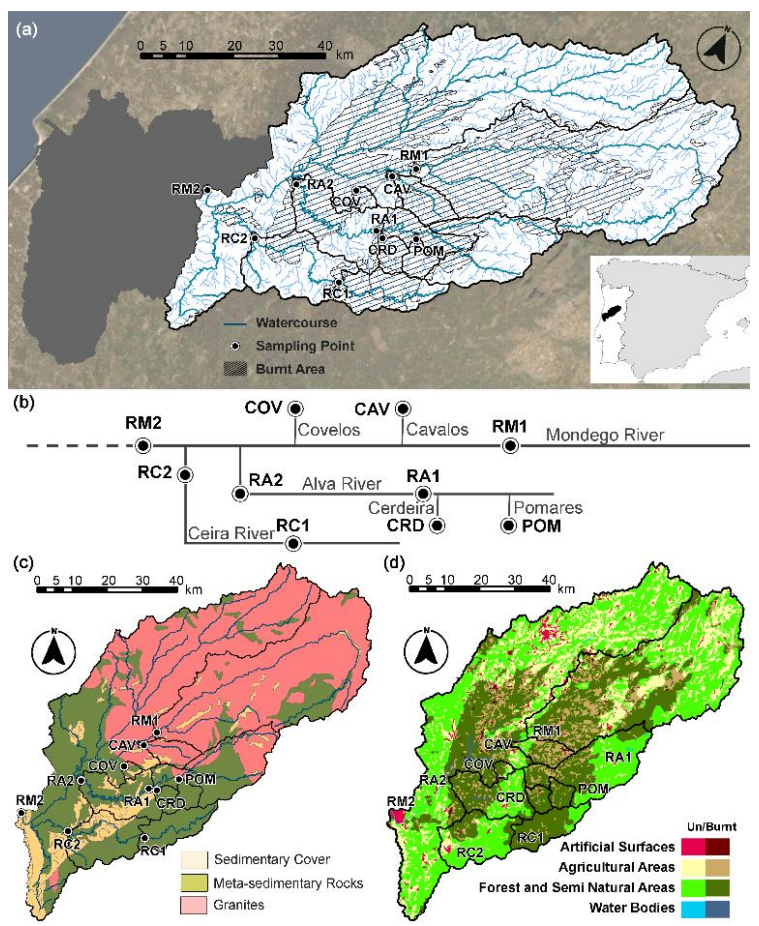

Figure 1. Location of the Mondego River hydrological basin in the Iberian Peninsula, with location of (a) the monitored basins and burnt area extent, (b) the watercourses hierarchy, (c) geologic context with sampling points overlay, and (d) land-use before the rural fires, with overlay of affected areas.

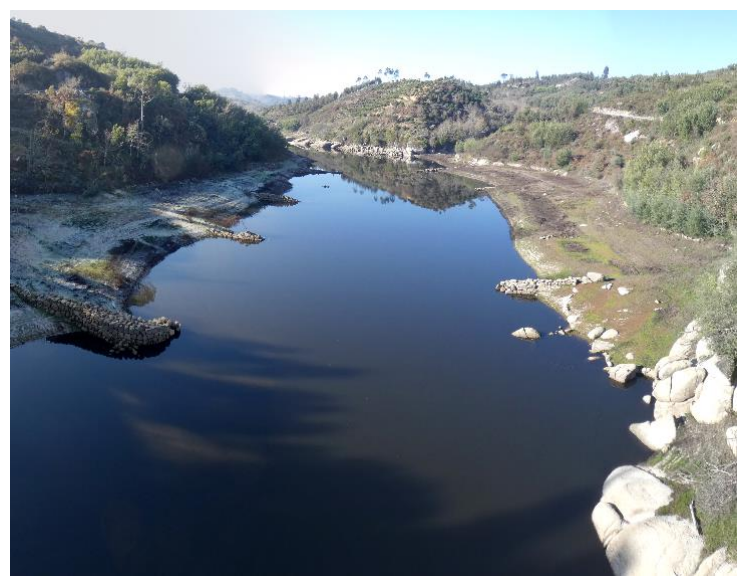

Figure 2. Presence of the remains of the fires with ashes by the Mondego River margins.

The Mondego River drainage basin is a highly contrasted area, from a geological and geomorphological standpoint. Geologically, it includes mainly metasedimentary units associated with Precambrian flysch sequences, in the southern areas, and to two-mica granitoids prevailing in the 
northeast (Figure 1c). Occasionally, Ordovician-Silurian metasedimentary units that include thick quartzite beds occur in the region. Some streams also drain Cretaceous-Cenozoic sedimentary units. The southeast mountain ridge (the Portuguese Central Chain), with embedded valleys and altitudes ranging from $200 \mathrm{~m}$ to $1200 \mathrm{~m}$, diverges from the northeast, is flatter upstream (200-500 m), and is almost flat downstream $(0-50 \mathrm{~m})$. The study area is mainly occupied by forests and semi-natural areas $(\geq 70 \%)$, comprising mainly maritime pines and eucalyptus. Upstream catchments also had considerable agricultural areas (Figure 1c). After the 2017 fires, some catchments (RC1, CRD, and POM) lost the majority of their forest cover ( $80 \%$ to $88 \%$ ), while others (RM1, CAV, and COV) lost significant agricultural areas (13.7\% to $40.1 \%$ ) (Figure $1 \mathrm{~d}$ ).

The Mondego River flows from northeast to southwest, for $258 \mathrm{~km}$, into the Atlantic Ocean, crossing the Caldeirão, Aguieira, Raiva, and Coimbra Dams. Of the main tributaries, it can be highlighted by the Dão, Corvo, Alva, and Ceira Rivers, the last two being part of the monitored area. The Alva River flows from East to west, for 110 km, crossing the Fronhas Dam, before joining the Mondego River. The Ceira River crosses the Alto do Ceira Dam, just $10 \mathrm{~km}$ from its spring, flows from east to west, for $100 \mathrm{~km}$, joining the Mondego River near Coimbra.

Previous studies on water quality in this basin have assessed the good quality in in terms of $\mathrm{pH}$, alkalinity and nitrogen species in the upstream areas [44]. Water shows higher mineralization in flatter granitic areas, contrasting with the steeper metamorphic areas [33]. Post-fire analysis of suspended sediments on the same basins have pointed to enhanced erosion, which in some sites even led to a complete removal of soil cover and the exposure of bare soil, ending up limiting local sediment supply [45]. Downstream, in the alluvial plain of Coimbra, there are some important ground water catchments, namely the Boavista wells capitation, responsible in 2017 for the distribution of water to 13 municipalities and more than 387,000 inhabitants [46].

The climate in the region is, according to the Köppen-Geiger climate classification, Mediterranean cool dry-summer [47]. The normal climate (1971-2000) for the closest stations shows the lowest rainfall in July (10.9 $\mathrm{mm}$ in Coimbra) (Figure 3a) and August (17.9 $\mathrm{mm}$ in Viseu) (Figure 3b) and the highest in December (126.2 $\mathrm{mm}$ to $203.4 \mathrm{~mm}$ ) [47] (Figure 3). September of 2017 was the driest in 87 years [48]. The first five months of the hydrological year 2017/2018 were dryer than normal, with $\sim 60 \%$ of normal rainfall, while March rainfall was 4.4-5.7 times higher than normal.
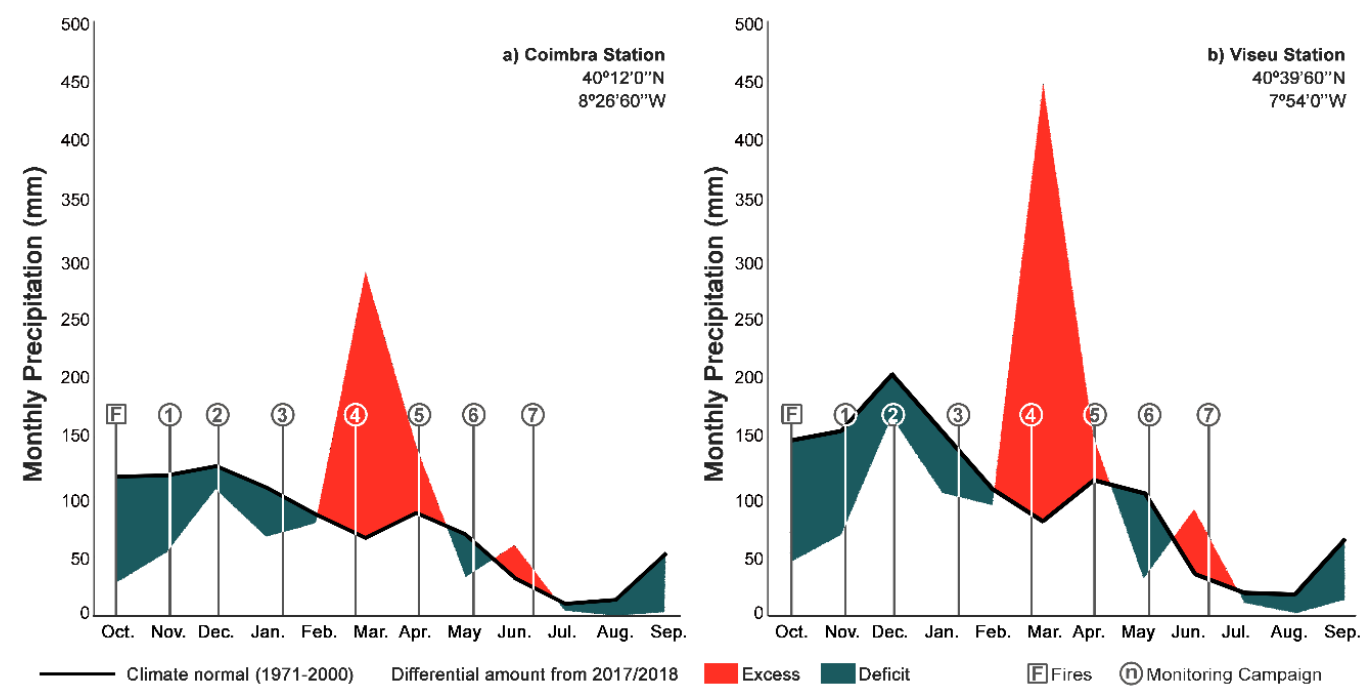

Figure 3. Normal precipitation from 1981-2010 and differential precipitation of the 2017/2018 hydrological year in the meteorological stations of: (a) Coimbra $\left(40^{\circ} 12^{\prime} 0^{\prime \prime} \mathrm{N} ; 8^{\circ} 26^{\prime} 60^{\prime \prime} \mathrm{W}\right.$ ) and (b) Viseu $\left(40^{\circ} 39^{\prime} 60^{\prime \prime} \mathrm{N} ; 7^{\circ} 54^{\prime} 0^{\prime \prime} \mathrm{W}\right)$. The date and number of the campaign is denoted by the circles. 


\subsection{Methodology}

A monitoring strategy was designed in accordance with the ISO 5667-1 International Standard [49]. From the selected three rivers (the Mondego, Alva, and Ceira), an upstream and a downstream sampling point was chosen, while four smaller streams (the Cavalos, Cerdeira, Covelo, and Pomares) were monitored near their mouths (Figure 1a). The monitoring campaigns were initiated one month after the fires, in the beginning of the precipitation period, and ended in June of 2018, in the end of the raining season. The monitoring campaigns were conducted monthly ( 29 to 44 day intervals). Water sampling was done in accordance with international standards $[49,50]$. Full details on sampling procedures are presented in [33].

\subsubsection{Field Parameters}

Electrical conductivity, $\mathrm{pH}$, water temperature $(\mathrm{Tw})$, and dissolved oxygen $(\mathrm{DO})$ were measured in situ using a multiparameter probe WTW multi 340i. Alkalinity was measured with a digital titrator, following an international standard [51]. The water's turbidity (Turb) was determined using the HANNA HI 93102 Turbidity Portable Meter (HI-93102, Hanna Instruments, Woonsocket, RI, USA).

\subsubsection{Laboratory Analysis and Quality Assurance}

The laboratory analysis featured some major and trace constituents. Ion chromatography and inductively coupled plasma optical emission spectrometry were used to analyze the concentrations of $\mathrm{Cl}^{-}, \mathrm{NO}_{3}{ }^{-}, \mathrm{SO}_{4}{ }^{2-}, \mathrm{Ca}^{2+}, \mathrm{Mg}^{2+}, \mathrm{Na}^{2+}$, and $\mathrm{K}^{+}$[52]. Trace constituents were determined by inductively coupled plasma optical emission spectrometry, for $\mathrm{Al}, \mathrm{Ba}, \mathrm{Cu}, \mathrm{Fe}, \mathrm{Mn}$, and $\mathrm{Zn}$, and by inductively coupled plasma mass spectrometry for $\mathrm{As}, \mathrm{Hg}$, and $\mathrm{Pb}$. The precisions for all analyzed elements and compounds are presented as Supplementary Material (Table S1).

\subsubsection{Determination of Geochemical Backgrounds}

Due to the immense burnt area it was unmanageable to create control points with comparable geological/geomorphological characteristics to all sampled basins. Therefore, the collected data was instead compared with 30 years of datasets (1980-2017) from these same catchments, obtained from network stations from the Portuguese Environmental Agency (APA). To establish a comparison range, we used an approach similar to the geochemical background, which is calculated through the median and the median absolute deviation (Mdn \pm 2MAD) [38] (Supplementary Material, Table S2). The median absolute deviation is calculated through the median of the absolute deviation from the dataset's median.

To compensate for the dilution-concentration effect, inherent to the relation between the precipitation and surface water, the selected historical data corresponded only to a high precipitation period in which the sampling campaigns occurred (November to April). In order to achieve statistical reliability, each calculated parameter had to have at least $50(\mathrm{~N})$ observations. Three scales were used, from the catchment size (Figure 4a), to the river (Figure 4b) and regional scale (Figure 4c). As smaller catchments have in general less observations, when this condition was not met for a parameter in a sampling site, the same methodology was applied at a higher scale. Due to the lack of previous records, it was not possible to establish backgrounds for $\mathrm{K}^{+}, \mathrm{Na}^{2+}$, and $\mathrm{SO}_{4}{ }^{2-}$. 


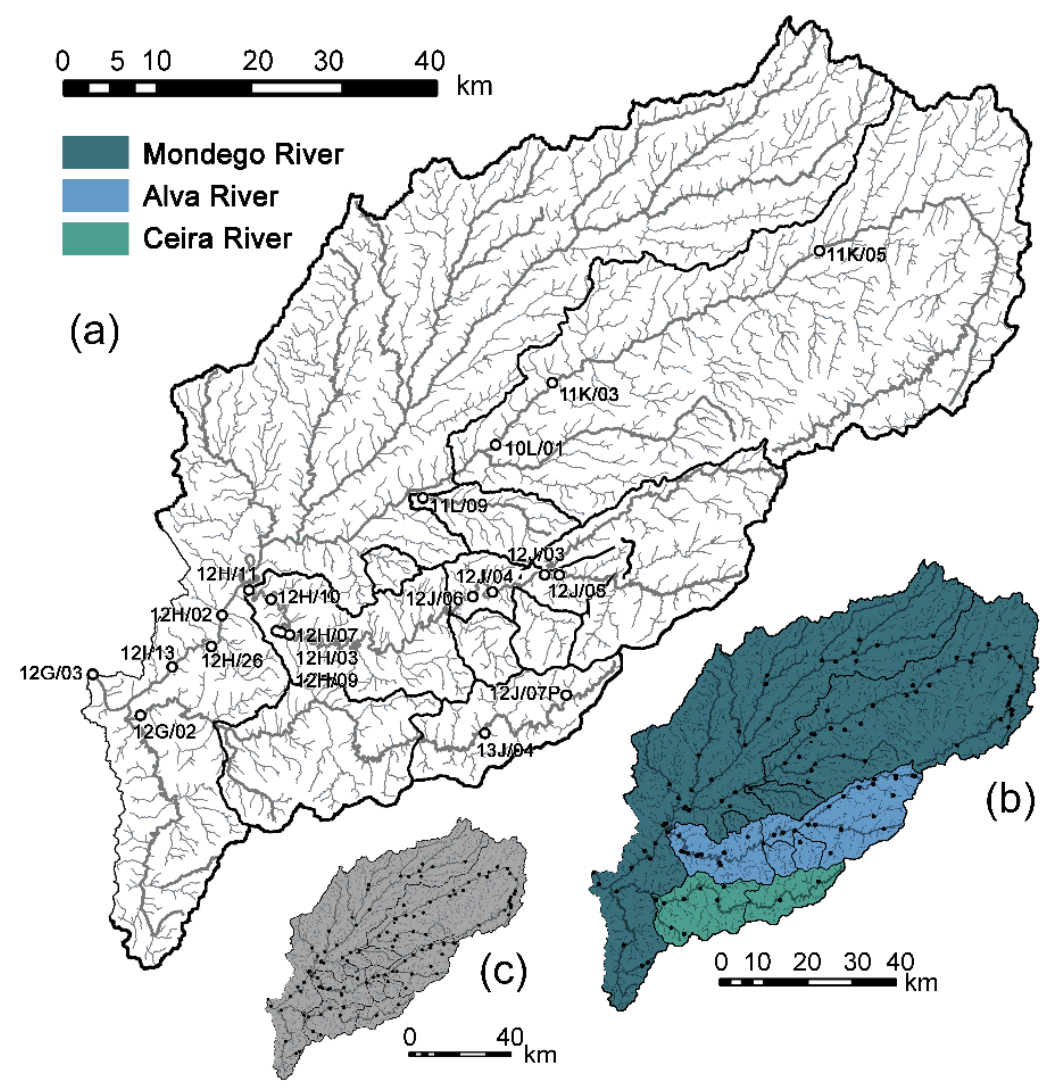

Figure 4. Location of the Portuguese Environmental Agency (APA) stations used to calculate the geochemical backgrounds, (a) at catchment scale, (b) river scale, and (c) regional scale.

\section{Results}

\subsection{Field Parameters}

River flowing in the granitic-dominated areas, which tend to be flatter (RM1, CAV, and RM2), has a higher electrical conductivity than in the steeper metamorphic-dominated catchments (POM, CRD, RA1, RA2, RC1, and RC2). This differentiation is valid for both the historic records and the monitoring campaigns performed for the present investigation. Most of the earlier campaigns also displayed higher values of electrical conductivity, and the intense precipitation of March and April seems to play a major role in reducing the dissolved substances in the surface water. The majority of the electrical conductivity for the sampled waters was above background between November and January (Figure 5).

The $\mathrm{pH}$ of the water remained similar in all sampled areas, with the month of March registering the lowest $\mathrm{pH}$, above the unpolluted rain's $\mathrm{pH}(\sim 5.2-5.5$; [53]), in almost all studied watercourses (Figure 5). During the highest precipitation months, March and April, the majority of the watercourses had lower $\mathrm{pH}$ than determined backgrounds, reaching an average of 6.5. 


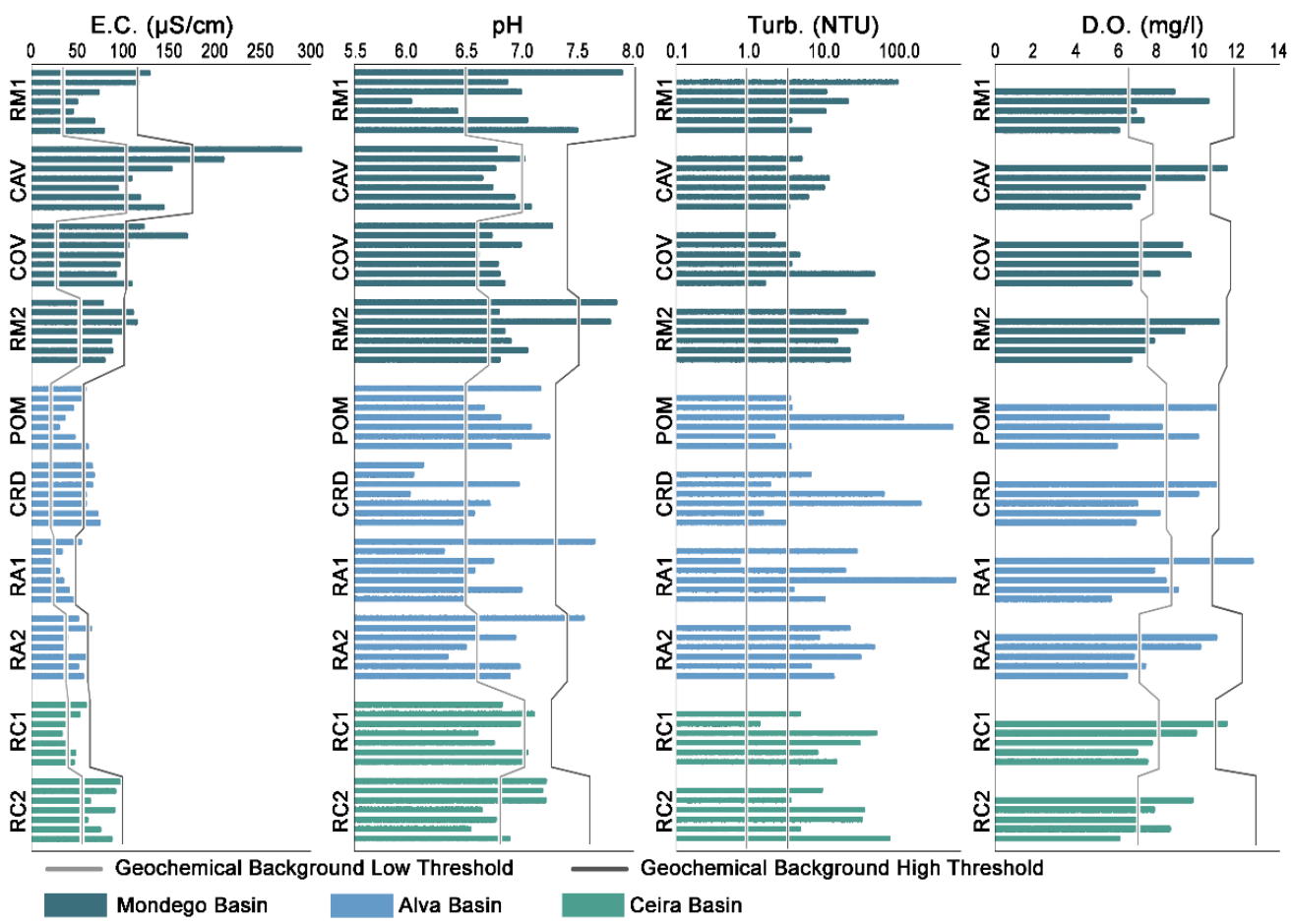

Figure 5. Temporal variations of electrical conductivity (E.C.) $(\mu \mathrm{S} / \mathrm{cm}), \mathrm{pH}$, turbidity (NTU), and dissolved oxygen (D.O.) (mg/L) juxtaposed with the calculated backgrounds. The lines represent the campaigns, from earlier on top to the latest on the bottom.

In the Mondego River, a major increase in turbidity was observed in December and January, while in its smaller tributaries this increase was much later, with the intense precipitation of March and April (Figure 5). Despite this, all the monitored points presented turbidity levels above the regional turbidity background, and occasionally above historical records. Dissolved oxygen concentration does not differ much between watercourses (Figure 5). In upstream sites, it was frequently above the background during winter time; by the end of the monitoring period, it was close or below the background in most locations.

\subsection{Major Ions}

The major ions analysis revealed more mineralized waters in the granitic-dominated basins, which presented the majority of the values above the background. In contrast, the metamorphic-dominated basins were generally less mineralized. Over the course of the monitoring program, reductions were observed in the concentrations of $\mathrm{Ca}^{2+}, \mathrm{Cl}^{-}, \mathrm{K}^{+}, \mathrm{Mg}^{2+}, \mathrm{Na}^{2+}$ and $\mathrm{SO}_{4}{ }^{2-}$ in almost all sites (Figure 6). Nevertheless, in the downstream site of Mondego River, $\mathrm{Ca}^{2+}, \mathrm{Mg}^{2+}$ and $\mathrm{SO}_{4}{ }^{2-}$ content actually increased until January 2018. Despite it was not possible to establish geochemical backgrounds for $\mathrm{Na}^{+}$ and $\mathrm{K}^{+}$, it is observable in one the most affected basins, the Covelo watercourse, an increase in the first precipitation period, of December and January. After that, most of the concentrations decreased over the course of the monitoring campaigns. 

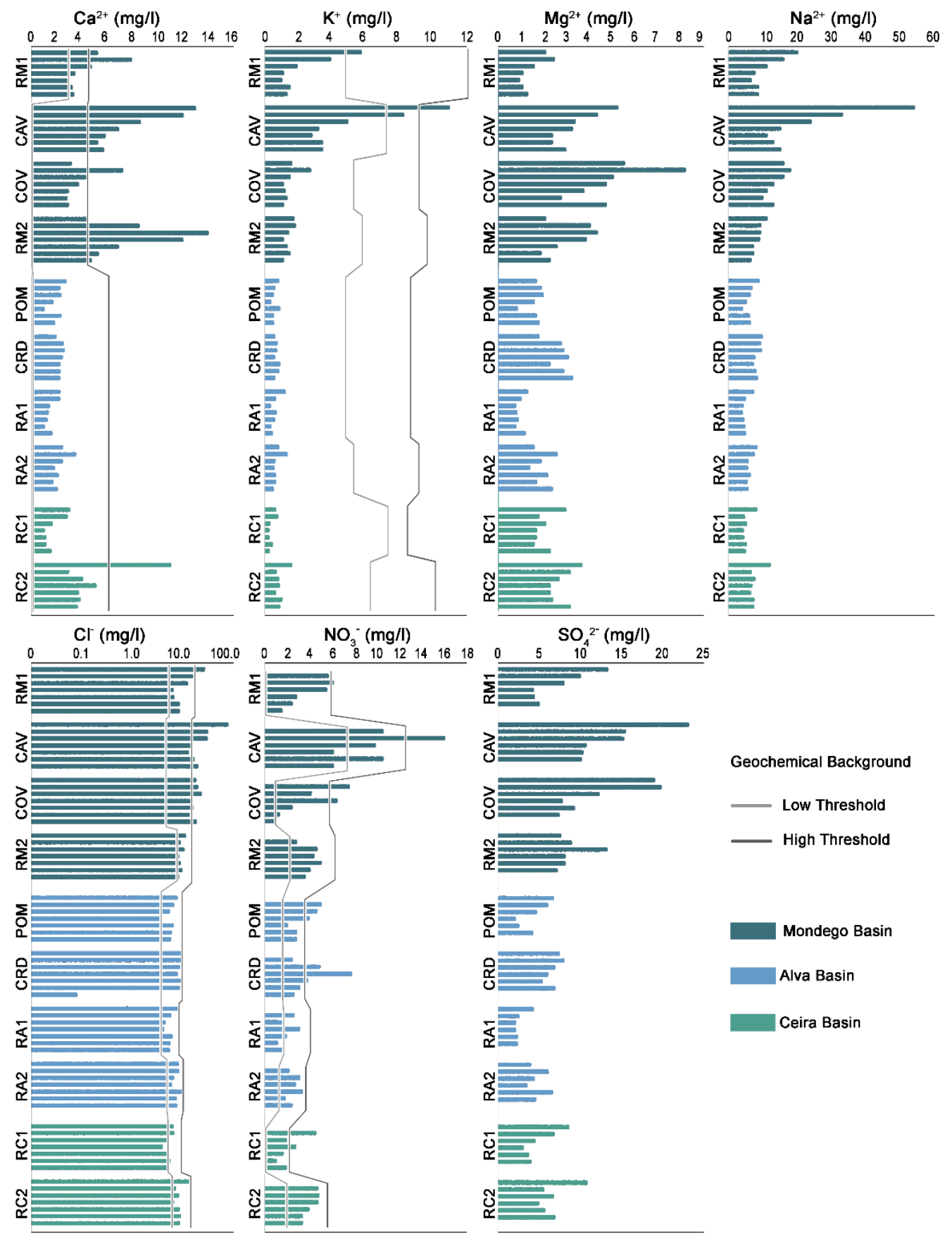

丰

๙를

틀

్ㅠ를
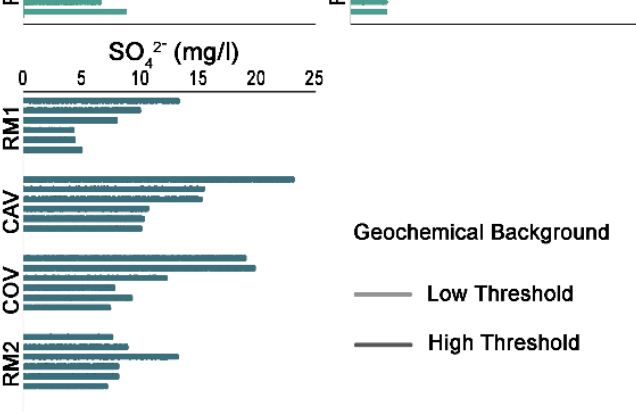

Geochemical Background

Low Threshold

High Threshold

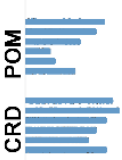

Mondego Basin

Alva Basin

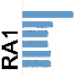

Ceira Basin

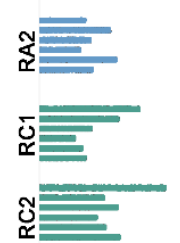

Figure 6. Evolution of major element concentrations that exceeded background concentrations during the campaigns. These are contrasted with the calculated geochemical background. The lines represent the campaigns, from earlier on top to latest on the bottom.

Most sampled waters presented $\mathrm{Ca}^{2+}, \mathrm{Cl}^{-}$, and $\mathrm{Mg}^{2+}$ content above the background in November, which remained until January for upstream areas, and until March and April for downstream areas. After intense precipitation occurred, there were increases in $\mathrm{NO}_{3}{ }^{-}$in all sampled watercourses, which may exceed the determined backgrounds in smaller watercourses and in upstream locations of Mondego and Ceira Rivers most clearly in January and March. After these precipitation periods, the $\mathrm{NO}_{3}{ }^{-}$concentrations return to normal concentrations. 


\subsection{Trace Elements}

Regarding minor and trace constituents, the bigger catchments tended to yield highest concentrations of $\mathrm{Fe}, \mathrm{Al}$, and $\mathrm{Mn}$, particularly immediately after the intense rainfall episodes of December. In general, a considerable change of $\mathrm{Al}$ content was observed from months with high precipitation to months with less precipitation. In the Mondego River, Al contents are frequently above background levels, being highest immediately after the first events of intense rainfall in December. In smaller metamorphic-dominated areas the peak values were found in March and April, when they frequently exceed background levels (Figure 7). As a general rule, higher Fe and Mn than calculated backgrounds were observed preferentially in November, December, and January.

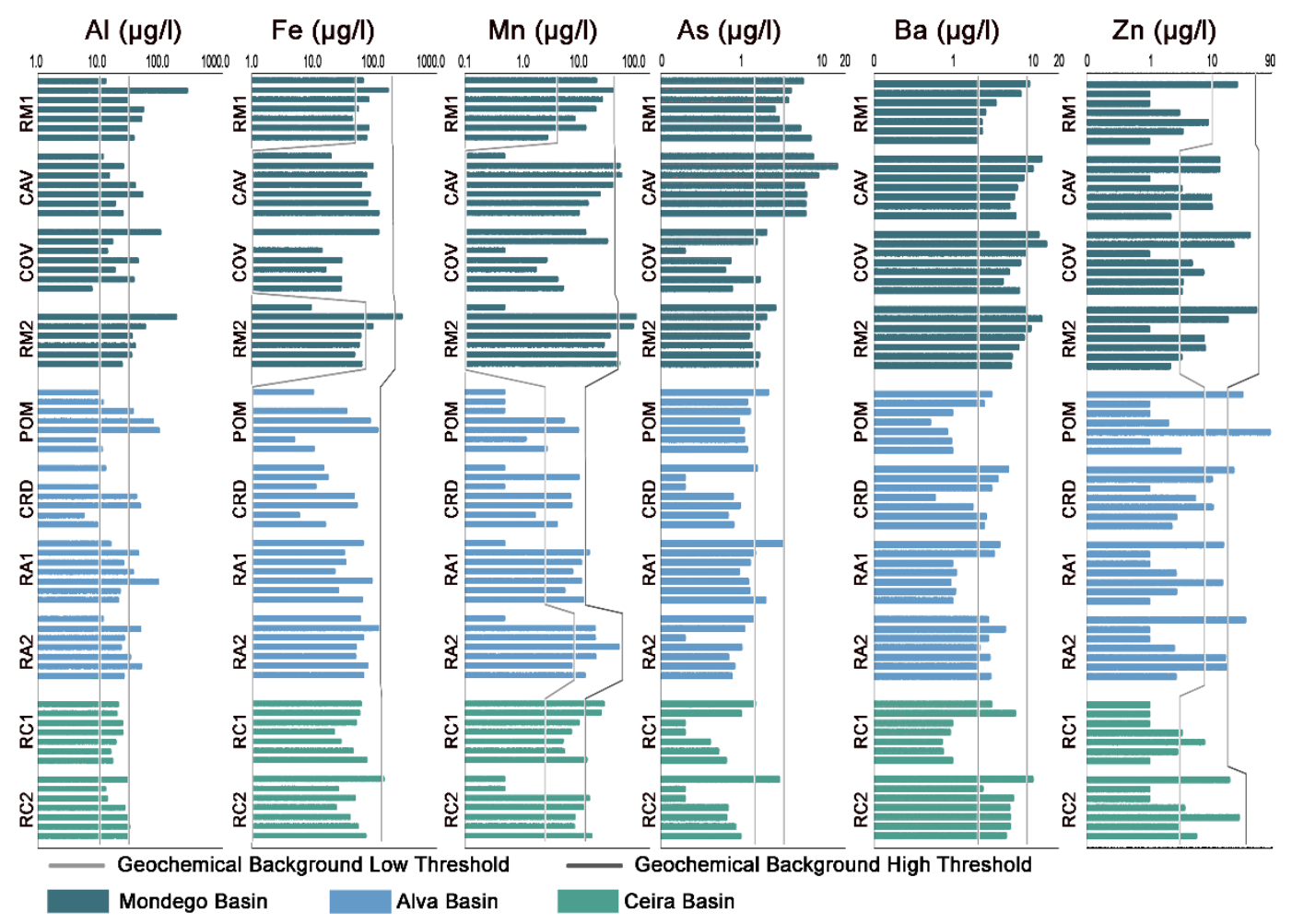

Figure 7. Evolution of trace element concentrations that exceeded background concentrations during the campaigns. These are contrasted with the calculated geochemical background. The lines represent the campaigns, from earlier on top to the latest on the bottom.

All monitored basins showed As in November, but its concentrations tended to decline through the monitoring period (Figure 6). An exception was visible in granitic-dominated catchment with intense agricultural occupation (Cavalos), where it increased in December. Actually, As only exceed background levels in catchments with extensive agricultural areas. Barium tended to be more abundant in granitic-dominated catchments, and may exceeded the background short after the wildfires, from November to January, but it is barely found on metamorphic-dominated catchments (Figure 7). Despite occasional April increases in some small rivers, earlier campaigns usually showed higher concentrations of $\mathrm{Zn}$ (Figure 7). Contrariwise, $\mathrm{Pb}$ was mostly found by the end of the monitoring period, in June, while $\mathrm{Cu}$ and $\mathrm{Hg}$ were always bellow quantifiable concentrations.

\section{Discussion}

In the studied area, water chemistry strongly depended on the geomorphology of the source areas. Both the campaign data as well as the historical datasets show that electrical conductivity and major and minor concentrations tend to be higher in the granite-dominated areas with low slopes 
$\left(4^{\circ}\right.$ to $\left.8^{\circ}\right)$, contrasting clearly with the metamorphic-dominated areas of higher slopes $\left(14^{\circ}\right.$ to $\left.18.5^{\circ}\right)$. This differentiation is attributed to the higher water-soil interactions due to longer residence time of the water in soil environments in flatter areas. The concentrations of some elements should also be influenced by the forms of land use in the catchment areas. For example, river water derived from areas where agricultural occupation is more common (e.g., in Cavalos River and the upstream site of the Mondego River) yields relatively high contents of $\mathrm{NO}_{3}{ }^{-}$and As. Although increasing As concentrations have been reported after wildfires elsewhere [22], this metalloid is also commonly found in phosphate fertilizers [54]. Hence, it is reasonable to assume that the high $\mathrm{NO}_{3}{ }^{-}$and As in these locations were originally sourced by fertilizers.

Wildfires are responsible for changes in water features that should also depend on geomorphic processes. The partial or full elimination of the vegetation cover frequently promotes enhanced erosion and sediment production $[24,27,55]$, with the transport of ash and sediments into watercourses leading to an increase in turbidity [56]. The combustion processes during the fire also increase the availability of some chemical species on the soil surface [22,57]. The shifts in water features, however, appear to be influenced by rainfall patterns. Three different periods with contrasting rainfall occurred after the wildfires of 2017 during the monitoring program (Figure 3). From November to January, rainfall was low and heavy, influenced by a severe draught occurring in Portugal. It became close to normal in February and abnormally high during March and April, returning to normal values in May. These precipitation periods are well reflected in the electrical conductivity and $\mathrm{Ba}$, with the rainfall highs synchronized with lows of these parameters.

The low precipitation period is marked by an overall increase in the concentrations of elements that tend to be hosted in ashes, such as $\mathrm{Cl}^{-}, \mathrm{SO}_{4}{ }^{2-}, \mathrm{NO}_{3}{ }^{-}$, and $\mathrm{Mn}$. High $\mathrm{Cl}^{-}$content was already linked with the leaching of ash deposits [22] and/or burnt plant litter [22,57], while $\mathrm{SO}_{4}{ }^{2-}$ can also be formed by oxidation of sulfur in the soil organic matter by combustion [22]. In central Portugal, increases in $\mathrm{SO}_{4}{ }^{2-}$ and $\mathrm{Cl}^{-}$after forest fires were also reported in springs of the Caramulo region [35] and in tributaries of the Águeda River [58]. Most sampled streams also revealed high $\mathrm{NO}_{3}{ }^{-}$at the beginning of the monitoring program, some until January and others until March. Nitrate ion might be formed by nitrification of $\mathrm{NH}_{4}{ }^{+}$due to the combustion of organic matter [57]. Finally, changes in Mn concentration have been linked with ashes and/or physicochemical changes of the organic matter, which provide water soluble Mn for soils in burnt areas [59]. Because eucalyptus bioaccumulates Mn and is abundant in forests of Central Portugal affected by the fires of 2017, it must have a major influence on the concentration of this element.

Despite $\mathrm{Zn}$ having been previously found in water in association with ashes in the suspended sediments [60], it had a minimal presence through the campaigns. Zn was observable in November in all the sampling points, achieving the highest concentration in March and April. In the next few months, it returned to unquantifiable concentrations in most of the basins, which can be related to a co-precipitation with Fe and/or Mn [54].

Elements associated with erosion and transport of soil particles, such as $\mathrm{Al}$ and $\mathrm{Fe}$, appear to be particularly abundant during November-December. High concentrations of these elements short after the Cerro Grande Fire of 2000 were attributed to enhanced suspended loads carried by the runoff [32]. However, these findings can also be attributed to soil organic matter interaction with mineral components of the soil, such as Fe and Al oxides [61], which were then released after the combustion into the watercourses. The March-April period of extreme precipitation showed renewed increases of $\mathrm{Al}, \mathrm{Fe}$, and $\mathrm{Mn}$ concentrations in some rivers. At this time, the $\mathrm{pH}$ measured in most watercourses were similar to uncontaminated rain and the lowest values of electrical conductivity were obtained. This displays how the rain was acting as a dilution agent, reducing the concentration of dissolved elements. Nevertheless, during March and April, turbidity reached highest values for most of the watercourses. It is noteworthy that, although less parameters exceeded calculated backgrounds (e.g., turbidity, $\mathrm{Cl}^{-}, \mathrm{NO}_{3}{ }^{-}$, and $\mathrm{Al}$ ) during this timeframe, this was when some reached more than five times those reference values. 


\section{Conclusions}

The geochemical background approach used in the present investigation allowed an assessment of fire effects on water quality, which is particularly useful where a comparison with control areas is not possible. This methodology is heavily influenced by the available data. In relatively big rivers, which tend to be better monitored by environmental agencies, the methodology provides close backgrounds for comparison, but where streams have received low attention backgrounds have to rely on data from monitored rivers in close proximity, giving less accurate estimations. Despite the used methodology is mostly utilized in economic geology, it can be used in environmental studies to detect anomalies related to contaminations. Also, although the geochemical background is mostly calculated for soils and sediments, as it was observed through the present study, it can also be used in surface waters, as long as the volume of the precipitation is taken into account.

The monthly monitoring periodicity allows the recognition of short term, direct and indirect, impacts of forest fires. The rural fires of 2017 did affect the quality of the surface water of the Mondego hydrological basin. An increase in turbidity was observed, likely due to the arrival of ashes, sediments and color-altering elements in the watercourses. Shifts in the concentrations of several elements were detected during the monitoring period. In an earlier stage shortly after the wildfires, they can be attributed to the presence of material derived from burnt organic matter (e.g., $\mathrm{Cl}^{-}, \mathrm{NO}_{3}{ }^{-}, \mathrm{SO}_{4}{ }^{2-}$, $\mathrm{Al}, \mathrm{As}, \mathrm{Fe}$, and $\mathrm{Mn}$ ). The increment of $\mathrm{Cl}^{-}$and $\mathrm{SO}_{4}{ }^{2-}$ was most evident in the downstream areas. The rise in the concentrations of $\mathrm{Mn}$ can be associated with the extensive burnt forest and natural areas that are occupied by eucalyptus, which bioaccumulates $\mathrm{Mn}$ in its leaves. $\mathrm{High}_{\mathrm{NO}_{3}}{ }^{-}$and As were found in basins with extensive agricultural areas, suggesting that these two contaminants are partially associated to agricultural activities. High rainfall events coincided with increases in turbidity and in the concentration of elements preferentially hosted in very fine-grained sediments (e.g., $\mathrm{Al}$ and $\mathrm{Fe}$ ), along with lower electrical conductivity and $\mathrm{pH}$ due to dilution effects by rain water.

Supplementary Materials: The following are available online at http://www.mdpi.com/2073-4441/12/10/2742/s1, Table S1: Precision values associated with the analyzed parameters, Table S2: Geochemical backgrounds calculated from monitoring stations data.

Author Contributions: Conceptualization, M.D.S., P.A.D. and A.O.T.; Methodology, M.D.S. and A.M.C.; Formal analysis, M.D.S. and A.M.C.; Investigation, M.D.S. and A.M.C.; Resources, A.M.C. and P.A.D.; Data curation, M.D.S.; Writing—original draft preparation, M.D.S. and A.O.T.; Writing-review and editing, M.D.S., P.A.D. and A.O.T.; Visualization, M.D.S. and A.M.C.; Supervision, A.O.T.; Project administration, A.O.T.; Funding acquisition, A.O.T. All authors have read and agreed to the published version of the manuscript.

Funding: This research was funded by the European Regional Development Fund (FEDER) through the Cooperation Program INTERREG Atlantic Area, grant number EAPA_272/2016.

Acknowledgments: This study is part of the RiskAquaSoil project, co-financed by the European Regional Development Fund (FEDER) through the Cooperation Program INTERREG Atlantic Area, with reference EAPA_272/2016.

Conflicts of Interest: The authors declare no conflict of interest.

\section{References}

1. Carvalho, J.; Lopes, J. Classificação de Incêndios Florestais. Manual do Utilizador; Direcção-Geral das Florestas: Lisboa, Portugal, 2001. (In Portuguese)

2. Nunes, M.C.; Vasconcelos, M.J.; Pereira, J.M.; Dasgupta, N.; Alldredge, R.J.; Rego, F.C. Land cover type and fire in Portugal: Do fires burn land cover selectively? Landsc. Ecology 2005, 20, 661-673. [CrossRef]

3. Mateus, P.; Fernandes, P.M. Forest fires in Portugal: Dynamics, causes and policies. In Forest Context and Policies in Portugal: Present and Future Challenges; Reboredo, F., Ed.; Springer: Cham, Germany, 2014; pp. 97-115.

4. Tedim, F.; Remelgado, R.; Carvalho, S.; Martins, J. The largest forest fires in Portugal: The constraints of burned area size on the comprehension of fire severity. J. Environ. Biol. 2015, 36, 133-143. [PubMed]

5. Nunes, A.N.; Lourenço, L.; Meira, A.C. Exploring spatial patterns and drivers of forest fires in Portugal (1980-2014). Sci. Total Environ. 2016, 573, 1190-1202. [CrossRef] [PubMed] 
6. Nunes, A.N. Regional variability and driving forces behind forest fires in Portugal an overview of the last three decades (1980-2009). Appl. Geogr. 2012, 34, 576-586. [CrossRef]

7. Ferreira-Leite, F.; Bento-Gonçalves, A.; Vieira, A.; Nunes, A.; Lourenço, L. Incidence and recurrence of large forest fires in mainland Portugal. Nat. Hazards 2016, 84, 1035-1053. [CrossRef]

8. Pereira, M.G.; Trigo, R.M.; da Camara, C.C.; Pereira, J.M.; Leite, S.M. Synoptic patterns associated with large summer forest fires in Portugal. Agric. For. Meteorol. 2005, 129, 11-25. [CrossRef]

9. Harding, A.; Palutikof, J.; Holt, T. The climate system. In The Physical Geography of the Mediterranean; Woodward, J., Ed.; Oxford University Press: Oxford, UK, 2009; pp. 69-88.

10. Moriondo, M.; Good, P.; Durao, R.; Bindi, M.; Giannakopoulos, C.; Corte-Real, J. Potential impact of climate change on fire risk in the Mediterranean area. Clim. Res. 2006, 31, 85-95. [CrossRef]

11. Turco, M.; Jerez, S.; Augusto, S.; Tarín-Carrasco, P.; Ratola, N.; Jiménez-Guerrero, P.; Trigo, R.M. Climate drivers of the 2017 devastating fires in Portugal. Sci. Rep. 2019, 9, 1-8. [CrossRef]

12. Nunes, L.J.R.; Meireles, C.I.R.; Gomes, C.J.P.; de Almeida Ribeiro, N.M.C. The Evolution of Climate Change in Portugal. In Climate Change Impact on Environmental Variability in the Forest; Nunes, L.J.R., Meireles, C.I.R., Gomes, C.J.P., de Almeida Ribeiro, N.M.C., Eds.; Springer: Cham, Germany, 2020; pp. 19-67.

13. Moreira, F.; Vaz, P.; Catry, F.; Silva, J.S. Regional variations in wildfire susceptibility of land-cover types in Portugal: Implications for landscape management to minimize fire hazard. Int. J. Wildland Fire 2009, 18, 563-574. [CrossRef]

14. Shakesby, R.A. Post-wildfire soil erosion in the Mediterranean: Review and future research directions. Earth-Sci. Rev. 2011, 105, 71-100. [CrossRef]

15. Nunes, A.N.; De Almeida, A.C.; Coelho, C.O. Impacts of land use and cover type on runoff and soil erosion in a marginal area of Portugal. Appl. Geogr. 2011, 31, 687-699. [CrossRef]

16. Pereira, P.; Úbeda, X.; Martin, D.; Mataix-Solera, J.; Cerdà, A.; Burguet, M. Wildfire effects on extractable elements in ash from a Pinus pinaster forest in Portugal. Hydrol. Process. 2014, 28, 3681-3690. [CrossRef]

17. Pausas, J.G. Changes in fire and climate in the eastern Iberian Peninsula (Mediterranean basin). Clim. Chang. 2004, 63, 337-350. [CrossRef]

18. Rego, F.; Louro, G.; Constantino, L. The impact of changing wildfire regimes on wood availability from Portuguese forests. For. Policy Econ. 2013, 29, 56-61. [CrossRef]

19. Ribeiro, C.; Valente, S.; Coelho, C.; Figueiredo, E. A look at forest fires in Portugal: Technical, institutional, and social perceptions. Scand. J. For. Res. 2015, 30, 317-325. [CrossRef]

20. Areia, N.; Intrigliolo, D.; Tavares, A.O.; Mendes, J.M.; Sequeira, M.D. The role of media between expert and lay knowledge: A study of Iberian media coverage on climate change. Sci. Total Environ. 2019, 682, 291-300. [CrossRef]

21. Viegas, D.X. Wildfires in Portugal. Fire Res. 2018, 2, 52. [CrossRef]

22. Smith, H.G.; Sheridan, G.J.; Lane, P.N.; Nyman, P.; Haydon, S. Wildfire effects on water quality in forest catchments: A review with implications for water supply. J. Hydrol. 2011, 396, 170-192. [CrossRef]

23. Rhoades, C.C.; Nunes, J.P.; Silins, U.; Doerr, S.H. The influence of wildfire on water quality and watershed processes: New insights and remaining challenges. Int. J. Wildland Fire 2019, 28, 721-725. [CrossRef]

24. Shakesby, R.A.; Doerr, S.H. Wildfire as a hydrological and geomorphological agent. Earth Sci. Rev. 2006, 74, 269-307. [CrossRef]

25. Varela, M.E.; Benito, E.; Keizer, J.J. Effects of wildfire and laboratory heating on soil aggregate stability of pine forest in Galicia: The role of lithology, soil organic matter content and water repellency. Catena 2010, 83, 127-134. [CrossRef]

26. Campos, I.; Abrantes, N.; Pereira, P.; Micaelo, A.C.; Vale, C.; Keizer, J.J. Forest fires as potential triggers for production and mobilization of polycyclic aromatic hydrocarbons to the terrestrial ecosystem. Land Degrad. Dev. 2019, 30, 2360-2370. [CrossRef]

27. Scott, D.F.; Versfeld, D.B.; Lesch, W. Erosion and sediment yield in relation to afforestation and fire in the mountains of the Western Cape Province, South Africa. S. Afr. Geogr. J. 1998, 80, 52-59. [CrossRef]

28. Keizer, J.J.; Doerr, S.H.; Malvar, M.C.; Prats, S.A.; Ferreira, R.S.V.; Oñate, M.G.; Coelho, C.O.A.; Ferreira, A.J.D. Temporal variation in topsoil water repellency in two recently burnt eucalypt stands in north-central Portugal. Catena 2008, 74, 192-204. [CrossRef]

29. Earl, S.R.; Blinn, D.W. Effects of wildfire ash on water chemistry and biotain South-Western USA stream. Freshw. Biol. 2003, 48, 1015-1030. [CrossRef] 
30. Lane, P.N.J.; Sheridan, G.J.; Noske, P.J.; Sherwin, C.B. Phosphorus and nitrogen exports from SE Australian forests following wildfire. J. Hydrol. 2008, 361, 186-198. [CrossRef]

31. Mast, M.A.; Clow, D.W. Effects of 2003 wildfires on stream chemistry in Glacier National Park. Montan. Hydrol. Process. 2008, 22, 5013-5023. [CrossRef]

32. Gallaher, B.; Koch, R. Quality of Storm Water Runoff at Los Alamos National Laboratory in 2000 with Emphasis on the Impact of the Cerro Grande Fire. Los Alamos National Laboratory LA-13926. Available online: https://pdfs.semanticscholar.org/45db/26759a2b60debfb6ce5ee1d0fc487ca7889d.pdf?_ga=2. 131141005.348100239.1582302245-895007879.1582302245 (accessed on 8 January 2020).

33. Sequeira, M.D.; Castilho, A.M.; Tavares, A.O.; Dinis, P. Assessment of superficial water quality of small catchment basins affected by Portuguese rural fires of 2017. Ecol. Indic. 2020, 111, 105961. [CrossRef]

34. Costa, M.R.; Calvão, A.R.; Aranha, J. Linking wildfire effects on soil and water chemistry of the Marão River watershed, Portugal, and biomass changes detected from Landsat imagery. Appl. Geochem. 2014, 44, 93-102. [CrossRef]

35. Mansilha, C.; Duarte, C.G.; Melo, A.; Ribeiro, J.; Flores, D.; Marques, J.E. Impact of wildfire on water quality in Caramulo Mountain ridge (Central Portugal). Sustain. Water Resour. Manag. 2019, 5, 319-331. [CrossRef]

36. Gałuszka, A.; Migaszewski, Z. Geochemical background-an environmental perspective. Mineralogia 2011, 42, 7-17. [CrossRef]

37. Hawkes, H.E.; Webb, J.S. Geochemistry in mineral exploration. Soil Sci. 1963, 95, 283. [CrossRef]

38. Reimann, C.; Filzmoser, P.; Garrett, R.G. Background and threshold: Critical comparison of methods of determination. Sci. Total Environ. 2005, 346, 1-16. [CrossRef] [PubMed]

39. Parrone, D.; Ghergo, S.; Preziosi, E. A multi-method approach for the assessment of natural background levels in groundwater. Sci. Total Environ. 2019, 659, 884-894. [CrossRef] [PubMed]

40. Rothwell, K.A.; Cooke, M.P. A comparison of methods used to calculate normal background concentrations of potentially toxic elements for urban soil. Sci. Total Environ. 2015, 532, 625-634. [CrossRef] [PubMed]

41. Viegas, D.X.; Figueiredo Almeida, M.; Ribeiro, L.M.; Raposo, J.; Viegas, M.T.; Oliveira, R.; Alves, D.; Pinto, C.; Jorge, H.; Rodrigues, A.; et al. O complexo de incêndios de Pedrógão Grande e concelhos limítrofes, iniciado a 17 de junho de 2017. Centro de Estudos sobre Incêndios Florestais da Faculdade de Ciências e Tecnologia da Universidade de Coimbra. Available online: https://www.portugal.gov.pt/download-ficheiros/ficheiro. aspx?v=3bb9773b-59fb-4099-9de5-a22fdcad1e3b (accessed on 6 January 2020).

42. Viegas, D.X.; Almeida, M.F.; Ribeiro, L.M. Análise dos incêndios florestais ocorridos a 15 de outubro de 2017. Análise dos incêndios florestais ocorridos a 15 de outubro de 2017. Centro de Estudos sobre Incêndios Florestais da Faculdade de Ciências e Tecnologia da Universidade de Coimbra. Available online: https://www.portugal.gov.pt/pt/gc21/comunicacao/documento?i=analise-dos-incendiosflorestais-ocorridos-a-15-de-outubro-de-2017 (accessed on 7 January 2020).

43. DGAPPF. Relatório Provisório de Incêndios Florestais: 2017. Instituto da Conservação da Natureza e das Florestas. Available online: www.icnf.pt/portal/florestas/dfci/Resource/doc/rel/2017/10-rel-prov-1jan-31out2017.pdf (accessed on 4 January 2020).

44. Ferreira, V.; Graça, M.A.; Feio, M.J.; Mieiro, C. Water quality in the Mondego river basin: Pollution and habitat heterogeneity. Limnetica 2004, 23, 295-306. [CrossRef]

45. Dinis, P.A.; Sequeira, M.; Tavares, A.O.; Carvalho, J.; Castilho, A.; Pinto, M.C. Post-wildfire denudation assessed from compositional features of river sediments (Central Portugal). Appl. Clay Sci. 2020, 193, 105675. [CrossRef]

46. AdCL. Relatório e Contas. Águas do Centro Litoral Grupo Águas de Portugal. Available online: http: //www.aguasdocentrolitoral.pt/pt/menu-de-topo/comunicacao/publicacoes/downloads/pub_pdf23_pt.pdf (accessed on 27 February 2020).

47. IPMA Clima Normais. Available online: https://www.ipma.pt (accessed on 5 January 2020).

48. IPMA Boletim Climatológico Setembro 2017 Mensal e Ano Hidrológico Portugal Continental. Instituto Português do Mar e da Atmosfera, I.P., Divisão de Clima e Alterações Climáticas. Available online: https://www.ipma.pt (accessed on 6 January 2020).

49. ISO Standard No. 5667-1. Water Quality-Sampling-Part 1: Guidance on the Design of Sampling Programmes and Sampling Techniques; European Committee for Standardization: Brussels, Belgium, 2006.

50. ISO Standard No. 5667-3. Water quality-Sampling-Part 3: Guidance on the Preservation and Handling of Water Samples; European Committee for Standardization: Brussels, Belgium, 2012. 
51. ISO Standard No. 9963-1. Water quality-Determination of Alkalinity-Part 1: Determination of Total and Composite Alkalinity; European Committee for Standardization: Brussels, Belgium, 1994.

52. Pedro, R.; Castilho, A.; Tavares, A. Surface water quality in a contrasted land-use river catchment. In IOP Conference Series: Earth and Environmental Science, Proceedings of the World Multidisciplinary Earth Sciences Symposium, Prague, Czech Republic, 3-7 September 2018; IOP Publishing: Bristol, UK, 2018. [CrossRef]

53. Santos, P.S.M.; Otero MSantos, E.B.H.; Duarte, A.C. Chemical composition of rainwater at a coastal town on the southwest of Europe: What changes in 20 years? Sci. Total Environ. 2011, 409, 3548-3553. [CrossRef]

54. Reimann, C.; De Caritat, P. Chemical Elements in the Environment: Factsheets for the Geochemist and Environmental Scientist; Springer Science \& Business Media: Berlin/Heidelberg, Germany, 2012.

55. Rulli, M.C.; Rosso, R. Modeling catchment erosion after wildfires in the San Gabriel Mountains of southern California. Geophys. Res. Lett. 2005, 32. [CrossRef]

56. Abraham, J.; Dowling, K.; Florentine, S. Risk of post-fire metal mobilization into surface water resources: A review. Sci. Total Env 2017, 599, 1740-1755. [CrossRef]

57. Khanna, P.K.; Raison, R.J. Effect of fire intensity on solution chemistry of surface soil under a Eucalyptus pauciflora forest. Aust. J. Soil Res. 1986, 24, 423-434. [CrossRef]

58. Ferreira, A.J.D.; Coelho, C.; Boulet, A.K.; Lopes, F.P. Temporal patterns of solute loss following wildfires in Central Portugal. Int. J. Wildland Fire 2005, 14, 401-412. [CrossRef]

59. Parra, J.G.; Rivero, V.C.; Lopez, T.I. Forms of Mn in soils affected by a forest fire. Sci. Total Environ. 2016, 181, 231-236. [CrossRef]

60. Burton, C.A.; Hoefen, T.M.; Plumlee, G.S.; Baumberger, K.L.; Backlin, A.R.; Gallegos, E.; Fisher, R.N. Trace elements in stormflow, ash, and burned soil following the 2009 Station Fire in Southern California. PLoS ONE 2016, 11, e0153372. [CrossRef] [PubMed]

61. Saidy, A.R.; Smernik, R.J.; Baldock, J.A.; Kaiser, K.; Sanderman, J. Microbial degradation of organic carbon sorbed to phyllosilicate clays with and without hydrous iron oxide coating. Eur. J. Soil Sci. 2015, 66, 83-94. [CrossRef]

(C) 2020 by the authors. Licensee MDPI, Basel, Switzerland. This article is an open access article distributed under the terms and conditions of the Creative Commons Attribution (CC BY) license (http://creativecommons.org/licenses/by/4.0/). 